\title{
Evaluation of model-simulated source contributions to tropospheric ozone with aircraft observations in the factor-projected space
}

\author{
C. Shim ${ }^{1, *}$, Y. Wang ${ }^{1}$, and Y. Yoshida ${ }^{2, * *}$ \\ ${ }^{1}$ Department of Earth and Atmospheric Sciences, Georgia Institute of Technology, 311 Ferst Drive, Atlanta, GA 30332, USA \\ ${ }^{2}$ Goddard Earth Science \& Technology Center, University of Maryland, Baltimore County, Baltimore, MD 21228, USA \\ * now at: Jet Propulsion Laboratory, California Institute of Technology, 4800 Oak Grove Drive Pasadena, CA 91109, USA \\ ** now at: Atmospheric Chemistry and Dynamics Branch, NASA Goddard Space Flight Center, Greenbelt, MD 20771, USA
}

Received: 4 October 2007 - Published in Atmos. Chem. Phys. Discuss.: 2 November 2007

Revised: 7 February 2008 - Accepted: 29 February 2008 - Published: 26 March 2008

\begin{abstract}
Trace gas measurements of TOPSE and TRACE$P$ experiments and corresponding global GEOS-Chem model simulations are analyzed with the Positive Matrix Factorization (PMF) method for model evaluation purposes. Specially, we evaluate the model simulated contributions to $\mathrm{O}_{3}$ variability from stratospheric transport, intercontinental transport, and production from urban/industry and biomass burning/biogenic sources. We select a suite of relatively longlived tracers, including 7 chemicals $\left(\mathrm{O}_{3}, \mathrm{NO}_{\mathrm{y}}, \mathrm{PAN}, \mathrm{CO}\right.$, $\mathrm{C}_{3} \mathrm{H}_{8}, \mathrm{CH}_{3} \mathrm{Cl}$, and ${ }^{7} \mathrm{Be}$ ) and 1 dynamic tracer (potential temperature). The largest discrepancy is found in the stratospheric contribution to ${ }^{7} \mathrm{Be}$. The model underestimates this contribution by a factor of 2-3, corresponding well to a reduction of ${ }^{7} \mathrm{Be}$ source by the same magnitude in the default setup of the standard GEOS-Chem model. In contrast, we find that the simulated $\mathrm{O}_{3}$ contributions from stratospheric transport are in reasonable agreement with those derived from the measurements. However, the springtime increasing trend over North America derived from the measurements are largely underestimated in the model, indicating that the magnitude of simulated stratospheric $\mathrm{O}_{3}$ source is reasonable but the temporal distribution needs improvement. The simulated $\mathrm{O}_{3}$ contributions from long-range transport and production from urban/industry and biomass burning/biogenic emissions are also in reasonable agreement with those derived from the measurements, although significant discrepancies are found for some regions.
\end{abstract}

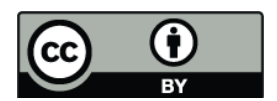

Correspondence to: C. Shim (cshim@jpl.nasa.gov)

\section{Introduction}

Tropospheric $\mathrm{O}_{3}$ has important environmental consequences. Photolysis of $\mathrm{O}_{3}$ and the subsequent reaction of $\mathrm{O}\left({ }^{1} \mathrm{D}\right)$ with water vapor $\left(\mathrm{H}_{2} \mathrm{O}\right)$ in troposphere produces the hydroxyl radical $(\mathrm{OH})$, which is the most important oxidant in troposphere. This tropospheric oxidation by $\mathrm{OH}$ determines the lifetime of major greenhouse gases such as methane $\left(\mathrm{CH}_{4}\right)$. The sources of tropospheric $\mathrm{O}_{3}$ include photochemical production within the troposphere and transport from the stratosphere. Many studies have investigated the main sources to tropospheric $\mathrm{O}_{3}$. Springtime $\mathrm{O}_{3}$ increase is attributed to photochemical production (e.g., Penkett and Brice, 1986 and Liu et al., 1987). A number of studies using 3-D chemical transport models have focused on the effect of intercontinental transport on tropospheric $\mathrm{O}_{3}$ concentrations from Asia to North America (e.g., Berntsen et al., 1999; Jaffe et al., 1999; Jacob et al., 1999; Bey et al., 2001). The effect of transPacific transport is particularly noticeable in the spring (e.g., Jacob et al., 1999; Mauzerall et al., 2000; Wild and Akimoto, 2001; Tanimoto et al., 2002; Wang et al., 1998, 2006). On the other hand, the studies based on the observed correlations between $\mathrm{O}_{3}$ and ${ }^{7} \mathrm{Be}$ attributed this trend to transport of stratospheric $\mathrm{O}_{3}$ (e.g., Oltmans and Levy, 1992; Dibb et al., 1994).

The observed relationships between tropospheric $\mathrm{O}_{3}$ and $\mathrm{CO}$ provide additional diagnosis of $\mathrm{O}_{3}$ sources (e.g., Fishman and Seiler, 1983; Chameides et al., 1987; Parrish et al., 1993). Furthermore, those relationships between simulated $\mathrm{CO}$ and $\mathrm{O}_{3}$ offer a reasonable way to evaluate model simulations of $\mathrm{O}_{3}$ (e.g., Chin et al., 1994). However, direct attribution of $\mathrm{O}_{3}$ sources based on atmospheric measurements is

Published by Copernicus Publications on behalf of the European Geosciences Union. 

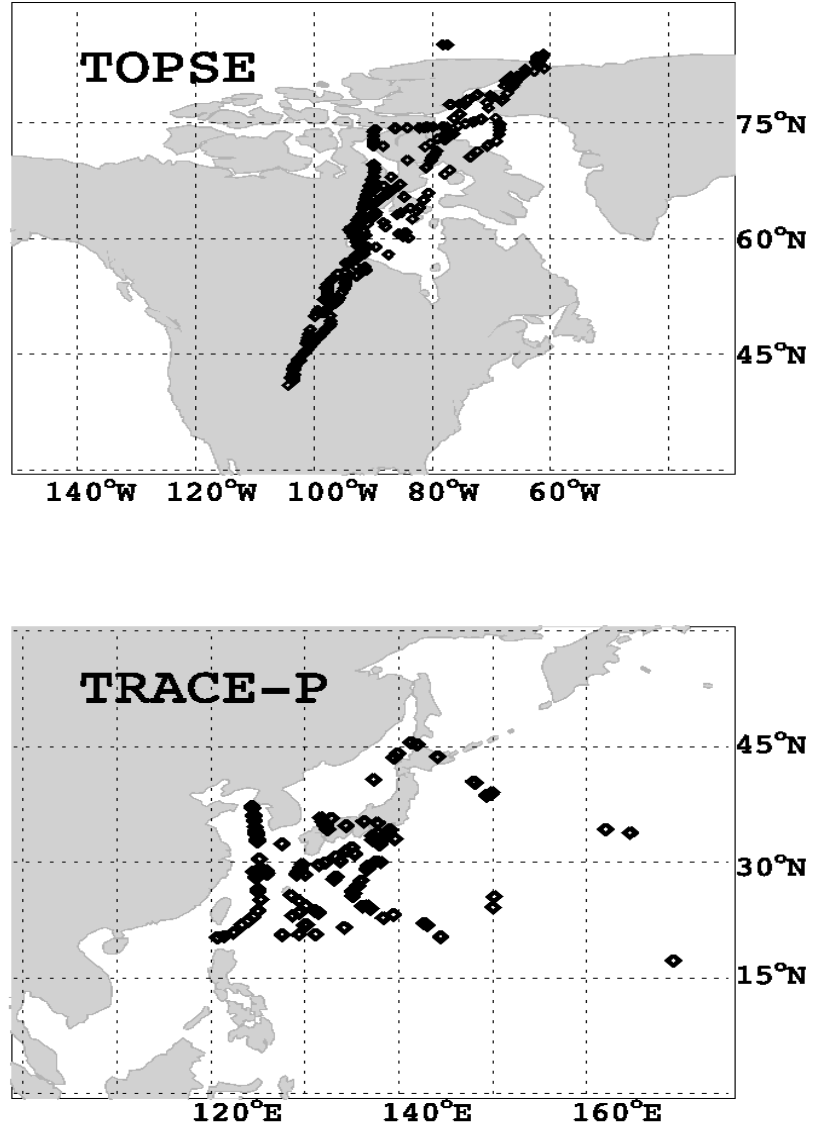

Fig. 1. Locations of aircraft measurements used in this study (after filtering).

difficult since tropospheric $\mathrm{O}_{3}$ is a secondary product from primary emissions of trace gases. One method we used previously to diagnose sources of tropospheric trace gases is the positive matrix factorization (PMF) method, an advanced multi-variant factor analysis (Wang et al., 2003b; Shim et al., 2007). PMF analysis of the measurements obtained during the Tropospheric Ozone Production about the Spring Equinox (TOPSE) experiment found that the increasing seasonal trend of springtime $\mathrm{O}_{3}$ at northern mid and high latitudes is attributed more to tropospheric $\mathrm{O}_{3}$ production and transport, even though $\mathrm{O}_{3}$ transport from the stratosphere is the largest contributor to $\mathrm{O}_{3}$ variability (Wang et al., 2003b).

The factor attributions based on atmospheric measurements provide additional constraints on model simulated tropospheric $\mathrm{O}_{3}$ sources beyond those provided by direct comparisons of simulated and observed trace gas concentrations. In this work, we apply the PMF method to the simulation results of a global 3-D chemical transport model (GEOSChem). As such, we can compare the PMF results to model simulations and evaluate the performance of GEOS-Chem on the basis of aircraft measurements. A main issue is how model simulated factor contributions to $\mathrm{O}_{3}$ variability com- pare with those based on the measurements. Unlike direct comparisons between observed and simulated trace gases, measurements and corresponding model results are first projected with PMF onto the factor space before model evaluation. In the factor space, a suite of chemicals can be evaluated simultaneously in a consistent and objective manner, which is difficult to achieve using direct comparisons between the measurements and model results. Aircraft measurements from two aircraft field campaigns, TOPSE and TRAnsport of Chemical Evolution over the Pacific (TRACE-P, MarchApril 2001) experiments are used. We describe data selections from TOPSE and TRACE-P and GEOS-Chem simulations in Sect. 2.1. The PMF method is explained in Sect. 2.2. Evaluation of model results in the projected factor space is discussed in Sect. 3. Conclusions are given in Sect. 4.

\section{Methodology}

\subsection{Measurements and GEOS-Chem simulations}

Figure 1 shows the measurement regions during TOPSE and TRACE-P. The TOPSE experiment (February-May 2000) was conducted to investigate the photochemical transition during spring at northern mid and high latitudes (Atlas et al., 2003). The TRACE-P experiment (March-April 2001) was conducted to investigate the Asian outflow to the Pacific (Jacob et al., 2003). Both experiments took place during spring when significant transport of $\mathrm{O}_{3}$ from the stratosphere is expected (e.g., Wang et al., 1998b and references therein)

In this study, we analyze relatively long-lived chemical tracers including $\mathrm{O}_{3}$, total reactive nitrogen $\left(\mathrm{NO}_{\mathrm{y}}\right)$, peroxyacetylnitrate (PAN), $\mathrm{CO}, \mathrm{C}_{3} \mathrm{H}_{8}, \mathrm{CH}_{3} \mathrm{Cl}$, and Beryllium-7 $\left({ }^{7} \mathrm{Be}\right)$ and one dynamic tracer (potential temperature). Those tracers other than $\mathrm{O}_{3}$ generally have specific primary source characteristics. $\mathrm{NO}_{\mathrm{y}}$ is a good tracer for air masses influenced by tropospheric $\mathrm{NO}_{\mathrm{x}}$ emissions (mostly from fossil fuel combustion, biomass burning, and soils) or transport from the stratosphere. PAN is produced only in the troposphere during oxidation of $>\mathrm{C}_{2}$ hydrocarbons and its lifetime increases rapidly with increasing altitude. Therefore, it is a good tracer for photochemically aged air masses in the free troposphere. $\mathrm{CO}$ is for combustion influence primarily from fossil fuel, biofuel, and biomass and $\mathrm{C}_{3} \mathrm{H}_{8}$ is a good liquefied petroleum gas (LPG) tracer. $\mathrm{CH}_{3} \mathrm{Cl}$ has its major sources from terrestrial biosphere and biomass burning (Yoshida et al., 2004, 2006). ${ }^{7} \mathrm{Be}$ is produced mainly by cosmic rays in the stratosphere and upper troposphere and is generally used as a tracer for stratospheric air mass (Dibb et al., 2003). Potential temperature is a useful dynamic tracer since it is conserved in adiabatic processes. The analytical approach for the observed species is similar to the work by Wang et al. (2003b), but the number of chemicals used is smaller because only measured species that are also simulated by GEOS-Chem are selected. The resulting discrepancies with 
the previous work by Wang et al. (2003b) will be discussed in Sect. 3.

Photochemical and dynamical environments vary dramatically with latitude. We separate the analysis regions to low, mid, and high latitudes. The TOPSE measurement data set is over mid $\left(40-60^{\circ} \mathrm{N}, 87-104^{\circ} \mathrm{W}\right)$ and high latitudes $(60$ $\left.85^{\circ} \mathrm{N}, 61-94^{\circ} \mathrm{W}\right)$. We consider only coincident measurements, which are mostly limited by availability of ${ }^{7} \mathrm{Be}$ measurements (144 coincident data points of all selected tracers for mid latitudes and 200 data points for high latitudes). Concentrations of $\mathrm{O}_{3}$ in the selected subset have a similar probability distribution as the whole dataset, and the derived spring $\mathrm{O}_{3}$ trends (TOPSE) of the subset are similar to the whole dataset. We exclude missing data because including large amounts of missing data (by assigning a large uncertainty to these data) would lead to a large underweight of the ${ }^{7} \mathrm{Be}$ measurements and a loss of ${ }^{7} \mathrm{Be}$ and $\mathrm{O}_{3}$ correlation signal (Wang et al., 2003b). The ${ }^{7} \mathrm{Be}$ and $\mathrm{O}_{3}$ correlation is critical for analyzing the effect of stratospheric transport. The selected data have a bias towards high altitudes of $5-8 \mathrm{~km}(\sim 70 \%$ of the data); therefore the evaluation results are more relevant for the middle and upper troposphere. The TRACE-P measurements data set is over mid latitudes $\left(30-45^{\circ} \mathrm{N}, 125-240^{\circ} \mathrm{E}\right.$, 65 data points) and low latitudes $\left(15-30^{\circ} \mathrm{N}, 120-205^{\circ} \mathrm{E}, 78\right.$ data points). The selected data also have a bias towards $7-$ $12 \mathrm{~km}\left(40-50 \%\right.$ of the data) due to the availability of ${ }^{7} \mathrm{Be}$ measurements.

GEOS-Chem is a global 3-D chemical transport model driven by assimilated meteorological data from the Global Modeling Assimilation Office (GMAO) (Schubert et al., 1993). The 3-D meteorological fields are updated every six hours, and the surface fields and mixing depths are updated every three hours. We use version 7.24 with a horizontal resolution of $2^{\circ} \times 2.5^{\circ}$ and 30 vertical layers (GEOS-3 meteorological fields were used). GEOS-Chem includes a comprehensive tropospheric $\mathrm{O}_{3}-\mathrm{NO}_{\mathrm{x}}-\mathrm{VOC}$ chemical mechanism (Bey et al., 2001), which includes the oxidation mechanisms of 6 VOCs (ethane, propane, lumped $>\mathrm{C}_{3}$ alkanes, lumped $>\mathrm{C}_{2}$ alkenes, isoprene, and terpenes). Climatological monthly mean biomass burning emissions are from Duncan et al. (2003). The fossil fuel emissions are from the Global Emission Inventory Activity (GEIA) for other chemical compounds (Benkovitz et al., 1996; Olivier et al., 2001). The cross-tropopause $\mathrm{O}_{3}$ transport from the stratosphere is simulated in the model using a passive ozone-like tracer (Synoz) (Mclinden et al., 2000). The annual net flux is $\sim 475 \mathrm{Tg}$ of $\mathrm{O}_{3}$. For standard simulations, the model was first spun up for one year. The GEOS-Chem simulations for the selected five tracers and one dynamic tracer $\left(\mathrm{O}_{3}, \mathrm{NO}_{\mathrm{y}}\right.$, PAN, $\mathrm{CO}, \mathrm{C}_{3} \mathrm{H}_{8}$, and potential temperature) are sampled at the same time and locations as the aircraft measurements. Simulated total reactive nitrogen $\left(\mathrm{NO}_{\mathrm{y}}\right)$ is estimated by the sum of simulated $\mathrm{NO}_{\mathrm{x}}, \mathrm{HNO}_{3}$ (nitric acid), $\mathrm{HNO}_{4}$ (pernitric acid), PAN, and $\mathrm{N}_{2} \mathrm{O}_{5}$ (dinitrogen pentoxide).
We follow Liu et al. (2001 and 2004) in ${ }^{7}$ Be simulations. The ${ }^{7} \mathrm{Be}$ source in GEOS-Chem is taken from the study by Lal and Peters (1967) as a function of altitude and latitude and $\sim 70 \%$ of ${ }^{7} \mathrm{Be}$ is emitted in the stratosphere. The seasonal and longitudinal dependence of ${ }^{7} \mathrm{Be}$ productions is very small and not considered. The major sink of atmospheric ${ }^{7} \mathrm{Be}$ is by wet deposition; the model considers scavenging in convective updrafts as well as first-order rainout and washout from both convective and large-scale precipitation (Liu et al., 2001). Liu et al. (2004) reduced the stratospheric ${ }^{7} \mathrm{Be}$ source by a factor of 3 . This simulation was first spun up for one year as well.

For model simulated $\mathrm{CH}_{3} \mathrm{Cl}$, we used the GEOS-Chem results by Yoshida et al. (2004). Contributions from the six sources (pseudo-biogenic, oceanic, biomass burning, incineration/industrial, salt mash and wet land) are considered. The model results are evaluated extensively with surface and aircraft measurements; the model simulations are usually in good agreement with measurements in the northern hemisphere.

In order to investigate the stratospheric $\mathrm{O}_{3}$ contributions in the model, we conducted tagged $\mathrm{O}_{3}$ simulations to track the fractions of $\mathrm{O}_{3}$ transported from the stratosphere (Liu et al., 2002). Photochemistry is considered in the simulations by taking archived $\mathrm{O}_{3}$ production and loss rates from the GEOS-Chem standard simulations on a daily basis. In this manner, when projecting simulated $\mathrm{O}_{3}$ variability in the factor space using PMF, we can examine the fractional contribution from the stratosphere as compared to tropospheric production (Sect. 3) in each factor.

\subsection{PMF applications}

The PMF method (Paatero and Tapper, 1994) explores factor categorization through the covariant structures of observed or simulated chemical and dynamical parameters (e.g., Paatero, 1997; Wang et al., 2003b; Liu et al., 2005). PMF generates only positive factor contributions, which enables a better physical interpretation of the results. In contrast, conventional the principal component analysis method lumps positively and negatively correlated tracers together. The data matrix $\mathbf{X}$ of $m$ measurements by $n$ tracers are decomposed in PMF analysis for $p$ factors as

$$
\mathbf{X}=\mathbf{G F}+\mathbf{E}
$$

Or

$x_{i j}=\sum_{k=1}^{p} g_{i k} f_{k j}+e_{i j}$

$i=1, \ldots, m ; j=1, \ldots, n ; k=1, \ldots, p$.

where the $m$ by $p$ matrix $\mathbf{G}$ is the mass contributions of $k$ th factor to $i$ th sample (factor score), the $p$ by $n$ matrix $\mathbf{F}$ is the gravimetric average contributions of $\mathrm{k}^{\text {th }}$ factor to $\mathrm{j}^{\text {th }}$ chemical species (factor loadings), and the $m$ by $n$ matrix $\mathbf{E}$ is the 


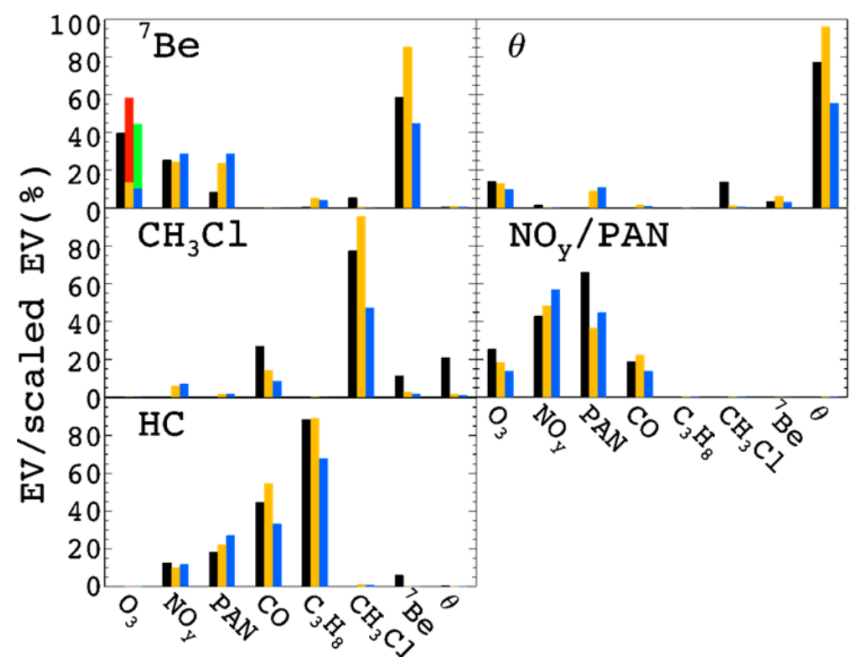

Fig. 2. Explained variation (\%, defined in Sect. 2.2) profiles of the observed (shown in black) and simulated datasets (shown in yellow and red) at mid latitudes $\left(40-60^{\circ} \mathrm{N}\right)$ during TOPSE. Also shown is the scaled EV profiles (in blue and green) for the simulated datasets for direct comparison with the measurements (Eq. 4, see text for details). The two-color bars for $\mathrm{O}_{3}$ show the model simulated stratospheric (upper bar, red or green) and tropospheric (lower bar, yellow or blue) fractions. The results are for measurement data with $\mathrm{O}_{3}$ concentrations $<100 \mathrm{ppbv}$ (and the corresponding model dataset).

error. In the PMF model, the solution is a weighted least squares fit, where the data uncertainties are used for determining the weights of the residuals in the error matrix. We also use the explained variation (EV),

$\mathrm{EV}_{k j}=\sum_{i=1}^{m}\left|g_{i k} f_{k j}\right| /\left[\sum_{i=1}^{m}\left(\sum_{k=1}^{p}\left|g_{i k} f_{k j}\right|+\left|e_{i j}\right|\right)\right]$

to define the relative contributions of each factor to chemical species since the mixing ratios of different compounds are not directly comparable.

During PMF analysis, it is important to choose the number of factors that provide physically meaningful results. In this analysis, the order factor is determined by sorting the centerof-mass locations of the $\mathbf{G}$ or $\mathbf{F}$ matrix in ascending order. By evaluating the error matrix $\mathbf{E}$, we define the range of mathematically acceptable number of factors (Paatero et al., 2002). We then inspect the factor profiles to choose the number of factors that gives the best physically meaningful results. In general, we pick as small a number of factors as possible to reduce the potential of overinterpreting of the dataset. Rotation is further used to improve factor separation (Paatero et al., 2002). However, the results presented in this work are insensitive to rotation.

As in the work by Wang et al. (2003b), the values of tracers are linearly scaled to a nondimensional range of $0-1$ and assigned uniformly small uncertainty for the dataset. The scaling is applied because the chemical and dynamical trac- ers have very different scales that affect the least square fitting in PMF. By scaling and assigning a uniform uncertainty, we assure that all tracers are weighted equally in the PMF analysis. In the analysis, we selected only coincident measurements of the selected tracers and corresponding model results. Missing measurement data are not used in order to reduce the uncertainty in the analysis. Following the procedure described above, PMF resolved 5 factors for TOPSE and 4 factors for TRACE-P in both observed and simulated datasets.

PMF was often used for source apportionments of surface aerosols (e.g., Lee et al., 1999). For that purpose, it is often necessary to assume that the composition of the air mass from a specific source does not change during transport. That assumption is unnecessary in this analysis since we evaluate how the simulated contributions to tropospheric ozone from different processes compare to the contributions derived from observations. Obviously the chemical characteristics of air masses are affected by transport. Our previous analyses (Wang et al., 2003b; Shim et al., 2007) indicate that although some collocated sources are mixed during transport, clear air mass separation based on the covariance of chemical and dynamical tracers can be obtained. We did not find evidence that transport and mixing "create" chemically distinct air mass.

\section{Results and discussion}

\subsection{TOPSE}

As mentioned in Sect. 2.1, the TOPSE results are biased toward the middle and upper troposphere. In order to capture the correlation between the stratospheric $\mathrm{O}_{3}$ and ${ }^{7} \mathrm{Be}$ using PMF, we have included the data points that have $\mathrm{O}_{3}$ concentrations $>100 \mathrm{ppbv}$ ( $5 \%$ of the data set), which are generally associated with the lower stratospheric air. When analyzing the PMF results, however, we only use data points with $\mathrm{O}_{3}<100 \mathrm{ppbv}$ to minimize the effect of these lower stratospheric data (Wang et al., 2003b). The simulated $\mathrm{O}_{3}$ mixing ratios do not exceed $100 \mathrm{ppbv}$. We analyze the datasets for mid $\left(40-60^{\circ}\right)$ and high $\left(60-85^{\circ}\right)$ latitudes separately.

\subsubsection{TOPSE at mid latitudes}

PMF derived EV profiles from the observed and simulated datasets for TOPSE mid latitudes are shown in Fig. 2. Each factor is named after the tracers that show the largest variability ( ${ }^{7} \mathrm{Be}, \theta, \mathrm{CH}_{3} \mathrm{Cl}, \mathrm{NO}_{\mathrm{y}} / \mathrm{PAN}$, and hydrocarbons). The figure shows reasonably consistent factor profiles between observed and simulated datasets (black and yellow/red bars). Direct comparison of the EV profiles between the observed and simulated datasets can be misleading when the simulated variability differ significantly from the observations. For the simulated datasets, we therefore also show the scaled EV 
Table 1. The factor scores correlations $(r)$ with latitude, altitude, and $\mathrm{C}_{2} \mathrm{H}_{6} / \mathrm{C}_{3} \mathrm{H}_{8}$ for TOPSE mid latitudes.

\begin{tabular}{lrrrrrr}
\hline & \multicolumn{2}{c}{ Latitude } & \multicolumn{2}{c}{ Altitude } & \multicolumn{2}{c}{$\mathrm{C}_{2} \mathrm{H}_{6} / \mathrm{C}_{3} \mathrm{H}_{8}$} \\
\hline Factors & Obs & Mod & Obs & Mod & Obs & Mod \\
\hline${ }^{7} \mathrm{Be}$ & -0.26 & -0.37 & 0.42 & 0.62 & 0.02 & 0.1 \\
$\theta$ & -0.59 & -0.51 & 0.65 & 0.75 & 0.61 & 0.43 \\
$\mathrm{CH}_{3} \mathrm{Cl}$ & -0.34 & -0.2 & 0.38 & 0.31 & 0.01 & 0.09 \\
$\mathrm{NO}_{\mathrm{y}} / \mathrm{PAN}$ & 0.32 & 0.32 & -0.12 & -0.1 & -0.23 & 0.07 \\
$\mathrm{HC}^{1}$ & 0.52 & 0.31 & -0.65 & -0.46 & -0.64 & -0.80 \\
\hline
\end{tabular}

Extreme factor scores (outside $2 \sigma$ range) and the measurements that have $\mathrm{O}_{3}$ greater than $100 \mathrm{ppbv}$ are excluded ${ }^{1} \mathrm{HC}$ denotes the hydrocarbon factor.

profiles (blue/green bars in Fig. 2-5) by the following equation,

$$
\left.\mathrm{EV}_{k j}\right|_{\text {scaled }}=\frac{\left(\sum_{i=1}^{m}\left|g_{i k} f_{k j}\right|\right)_{\text {model }}}{\left[\sum_{i=1}^{m}\left(\sum_{k=1}^{p}\left|g_{i k} f_{k j}\right|+\left|e_{i j}\right|\right)\right]_{\text {measurements }}}
$$

The ${ }^{7} \mathrm{Be}$ factor in Fig. 2 shows the largest variability of ${ }^{7} \mathrm{Be}$ for both observations and model $(60 \%$ and 237 femtocurie per square centimeter ( $\mathrm{fCi} / \mathrm{SCM}$ ) for the observations, $85 \%$ and $188 \mathrm{fCi} / \mathrm{SCM}$ for the model), indicating the stratospheric origin of the air masses. The stratospheric $\mathrm{O}_{3}$ fraction from tagged $\mathrm{O}_{3}$ simulation in this factor show $\sim 75 \%$ of the stratospheric origin, and a small fraction of the tropospheric ${ }^{7} \mathrm{Be}$ origin ( $\sim 25 \%$ ), due likely to upper tropospheric ${ }^{7}$ Be production, which is also evident in the small fractions of PAN in this factor. The ${ }^{7} \mathrm{Be}$ factor is associated with the largest $\mathrm{O}_{3}$ variability at mid latitudes ( $40 \%$ and $20 \mathrm{ppbv}$ for the observations, $58 \%$ and $14 \mathrm{ppbv}$ for the model). A notable underestimation in the simulated ${ }^{7} \mathrm{Be}$ mean concentration is found (435 and $234 \mathrm{fCi} / \mathrm{SCM}$ for the observations and model, respectively). Including measured $\mathrm{O}_{3}$ data $>100 \mathrm{ppbv}$ in the ${ }^{7} \mathrm{Be}$ factor profile do not alter the results except a small decrease of the scaled $\mathrm{EV}$ of $\mathrm{O}_{3}$. The same result is found for other regions, we therefore only show the profiles with measured $\mathrm{O}_{3} \leq 100 \mathrm{ppbv}$.

We examine the factor correlations with latitudes, altitude, and $\mathrm{C}_{2} \mathrm{H}_{6} / \mathrm{C}_{3} \mathrm{H}_{8}$ ratio in order to further investigate the factor characteristics (Table 1). The higher $\mathrm{C}_{2} \mathrm{H}_{6} / \mathrm{C}_{3} \mathrm{H}_{8}$ ratio reflects photochemically aged air masses (Wang and Zeng, 2004). The positive correlations of the ${ }^{7} \mathrm{Be}$ factor with altitude ( $r=0.42$ and 0.62 for the observed and simulated datasets, respectively) are expected for a factor dominated by transport from the stratosphere. The weak negative correlations with latitude indicate that stratosphere-troposphere exchange is likely more active at lower latitudes in $40-60^{\circ} \mathrm{N}$ region (Table 1).

The potential temperature $(\theta)$ factor has large variability of $\theta$ (Fig. 2). It explains $14 \%$ of observed $\mathrm{O}_{3}$ vari-

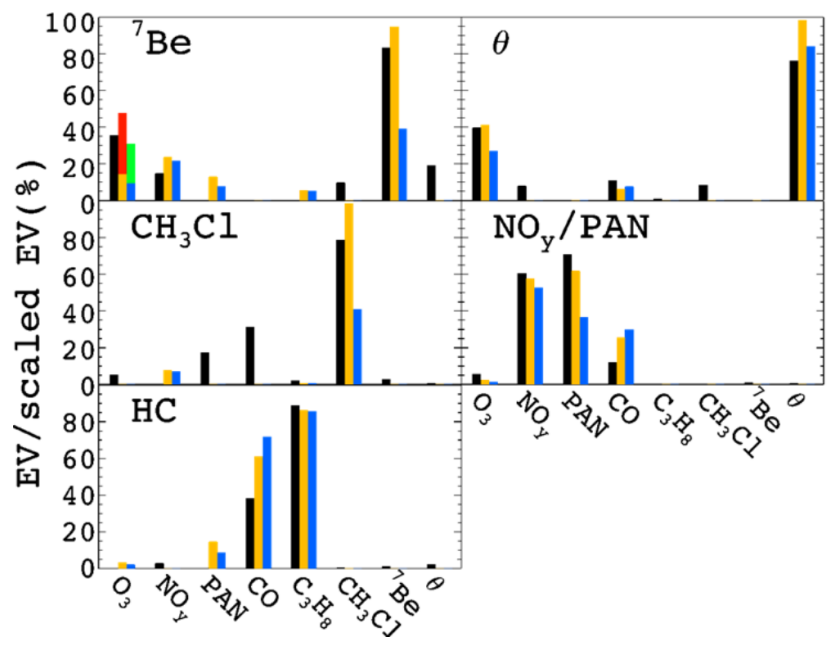

Fig. 3. Same as Fig. 2, but for TOPSE high latitudes $\left(60-85^{\circ} \mathrm{N}\right)$.

ability (3.6 ppbv) and $12.8 \%$ of simulated $\mathrm{O}_{3}$ variability (3.1 ppbv). The negative factor correlations with latitude and $\mathrm{CO}(r=-0.64$ and -0.52 , respectively, not shown in the table), and positive correlations with altitudes and $\mathrm{C}_{2} \mathrm{H}_{6} / \mathrm{C}_{3} \mathrm{H}_{8}$ ratio (Table 1) imply that this factor is likely associated with intercontinental long-range transport of $\mathrm{O}_{3}$ from lower latitudes, which is consistent with the result by Wang et al. (2003b).

The $\mathrm{CH}_{3} \mathrm{Cl}$ factor is characterized by large signals of $\mathrm{CH}_{3} \mathrm{Cl}$ and no $\mathrm{O}_{3}$ variability is explained by this factor (Fig. 2). This factor contains significant $\mathrm{CO}$ variability, which can imply the biomass burning influence. However, the very small factor correlations with $\mathrm{C}_{2} \mathrm{H}_{6} / \mathrm{C}_{3} \mathrm{H}_{8}$ ratio and negative correlation with latitude (Table 1) may support the large biogenic $\mathrm{CH}_{3} \mathrm{Cl}$ emissions from the tropics (e.g., Yoshida et al., 2004, 2006) rather than biomass burning.

The $\mathrm{NO}_{\mathrm{y}} / \mathrm{PAN}$ factor has large signals of $\mathrm{NO}_{\mathrm{y}}$ and PAN (Fig. 2) and this factor is the second important factor for tropospheric $\mathrm{O}_{3}$ variability at mid latitudes $(25.6 \%$ and $6.6 \mathrm{ppbv}$ for the observations, $18.4 \%$ and $4.4 \mathrm{ppbv}$ for the model). The positive correlation with latitude and much weaker correlations with altitude and $\mathrm{C}_{2} \mathrm{H}_{6} / \mathrm{C}_{3} \mathrm{H}_{8}$ ratio (Table 1) imply that the factor represents long-range transport of reactive nitrogen.

The hydrocarbon factor is characterized by large variability of $\mathrm{CO}$ and $\mathrm{C}_{3} \mathrm{H}_{8}$ (Fig. 2). There is no contribution to tropospheric $\mathrm{O}_{3}$ variability. The positive correlation with latitude and clear negative correlations with altitudes and $\mathrm{C}_{2} \mathrm{H}_{6} / \mathrm{C}_{3} \mathrm{H}_{8}$ ratio reflect the influence of relatively fresh emissions from the surface (Table 1).

\subsubsection{TOPSE at high latitudes}

Five factors are identified for high latitudes $\left({ }^{7} \mathrm{Be}, \theta, \mathrm{CH}_{3} \mathrm{Cl}\right.$, $\mathrm{NO}_{\mathrm{y}} / \mathrm{PAN}$, and hydrocarbons; Fig. 3). As mid latitudes, there is also significant difference in ${ }^{7} \mathrm{Be}$ variability 
Table 2. Same as Table 1, but for TOPSE high latitudes.

\begin{tabular}{lrrrrrr}
\hline & \multicolumn{2}{c}{ Latitude } & \multicolumn{2}{c}{ Altitude } & \multicolumn{2}{c}{$\mathrm{C}_{2} \mathrm{H}_{6} / \mathrm{C}_{3} \mathrm{H}_{8}$} \\
\hline Factors & Obs & Mod & Obs & Mod & Obs & Mod \\
\hline${ }^{7} \mathrm{Be}$ & -0.08 & -0.08 & 0.48 & 0.4 & 0.25 & 0.11 \\
$\theta$ & -0.1 & -0.2 & 0.51 & 0.55 & 0.22 & 0.4 \\
$\mathrm{CH}_{3} \mathrm{Cl}$ & -0.07 & -0.2 & 0.38 & 0.46 & 0.18 & -0.18 \\
$\mathrm{NO}_{\mathrm{y}} / \mathrm{PAN}$ & 0.16 & 0.07 & 0.02 & -0.34 & 0.25 & -0.14 \\
$\mathrm{HC}^{1}$ & -0.08 & 0.04 & -0.43 & -0.49 & -0.77 & -0.79 \\
\hline
\end{tabular}

between observations and simulation $(415 \mathrm{fCi} / \mathrm{SCM}$ and 206 $\mathrm{fCi} / \mathrm{SCM}$, respectively) in the ${ }^{7} \mathrm{Be}$ factor, reflecting serious underestimation of ${ }^{7} \mathrm{Be}$ by GEOS-Chem. Liu et al. (2001) artificially scaled down the stratospheric ${ }^{7} \mathrm{Be}$ source by a factor of $\sim 3$ in order to adjust for some surface measurements of ${ }^{7} \mathrm{Be}$. However, the simulated ${ }^{7} \mathrm{Be}$ mean concentrations and the variability accounted for in the ${ }^{7} \mathrm{Be}$ factor show consistent underestimations by about a factor of 2 in TOPSE and TRACE-P (to be shown) datasets. It implies that the factor of 3 reduction in the stratospheric ${ }^{7} \mathrm{Be}$ source in the standard GEOS-Chem model is too large.

The ${ }^{7} \mathrm{Be}$ factor shows comparable $\mathrm{O}_{3}$ variabilities between observations and simulation ( $34 \%$ and $13.7 \mathrm{ppbv}$ for the observations, $45 \%$ and $12.4 \mathrm{ppbv}$ for the model). The stratospheric $\mathrm{O}_{3}$ fraction from the tagged $\mathrm{O}_{3}$ simulation suggests that $\sim 70 \%$ is of the stratospheric origin (Fig. 3). The tropospheric fraction for $\mathrm{O}_{3}$ is $\sim 30 \%$ in this factor. The positive correlations with altitude and negative correlations with $\mathrm{CO}$ support its stratospheric origin (Table 2).

The potential temperature $(\theta)$ factor shows large variabilities of $\theta$ (Fig. 3). Its contributions to $\mathrm{O}_{3}$ levels are as much as that of the ${ }^{7} \mathrm{Be}$ factor $(39 \%$ and $15.4 \mathrm{ppbv}$ for the observations, $41 \%$ and $10.7 \mathrm{ppbv}$ for the model), which is different from mid latitudes. The positive correlation with altitude and $\mathrm{C}_{2} \mathrm{H}_{6} / \mathrm{C}_{3} \mathrm{H}_{8}$ ratio (Table 2) indicates that this factor is likely associated with transport of reactive-nitrogen poor air masses from lower latitudes. Tagged $\mathrm{O}_{3}$ simulation shows that $\mathrm{O}_{3}$ variability accounted for in this factor is produced in the troposphere (Fig. 3).

The $\mathrm{CH}_{3} \mathrm{Cl}$ factor is characterized by large signals of $\mathrm{CH}_{3} \mathrm{Cl}(78 \%$ and $38.6 \mathrm{pptv}$ for the observations, $98 \%$ and 20.3 pptv for the model), but its contribution to $\mathrm{O}_{3}$ variability is insignificant. This factor is positively correlated with altitude, consistent with long-range transport of high $\mathrm{CH}_{3} \mathrm{Cl}$ air masses from lower latitudes since there are no significant sources of $\mathrm{CH}_{3} \mathrm{Cl}$ at high latitudes.

The $\mathrm{NO}_{\mathrm{y}} / \mathrm{PAN}$ factor has large signals of $\mathrm{NO}_{\mathrm{y}}$ and PAN (Fig. 3). This factor also has clear chemical signals of $\mathrm{CO}$ but not ${ }^{7} \mathrm{Be}$, implying that the air masses are influenced by industrial/fossil fuel emissions at high latitudes (Table 2). This factor, however, contributes to less than $5 \%$ of $\mathrm{O}_{3}$ variability, reflecting the largely inactive photochemical environment at high latitudes in spring (Wang at al., 2003a).
Table 3. Factor contributions to $\mathrm{O}_{3}$ seasonal increase (ppbv/month) for TOPSE.

\begin{tabular}{lrrrr}
\hline & \multicolumn{2}{c}{ Mid latitudes } & \multicolumn{2}{c}{ High latitudes } \\
\hline Factors & Obs & Mod & Obs & Mod \\
\hline${ }^{7} \mathrm{Be}$ & 2.7 & 1.3 & 1.8 & 0.8 \\
$\theta$ & 0.3 & 0.4 & 1.2 & 0.8 \\
$\mathrm{CH}_{3} \mathrm{Cl}$ & 0 & 0 & 0.3 & 0 \\
$\mathrm{NO}_{\mathrm{y}} / \mathrm{PAN}$ & 3.5 & 1.3 & 1.1 & 0.1 \\
$\mathrm{HC}$ & 0 & 0 & 0 & -0.4 \\
Total & 6.5 & 3.0 & 4.3 & 1.3 \\
\hline
\end{tabular}

Only the measurements $\mathrm{O}_{3}<100$ ppbv are analyzed.

The hydrocarbon factor is characterized by a large variability of $\mathrm{CO}$ and $\mathrm{C}_{3} \mathrm{H}_{8}$ (Fig. 3). It does not contribute to tropospheric $\mathrm{O}_{3}$ variability. Just as mid latitudes, the negative correlations with altitude and $\mathrm{C}_{2} \mathrm{H}_{6} / \mathrm{C}_{3} \mathrm{H}_{8}$ ratio reflect air masses affected by relatively fresh emissions (Table 2).

\subsubsection{Springtime $\mathrm{O}_{3}$ trends at northern mid and high lati- tudes}

Understanding the contributions to the seasonal $\mathrm{O}_{3}$ trend is another important purpose of this study. As stated in Sect. 2.1, this study analyzed only eight tracers due to the limited availability of simulated tracers, while the previous study (Wang et al., 2003b, hereafter referred to as the previous study) included fourteen tracers with seven factors. At mid latitudes, the seasonal increase of all factors of measurements is $6.48 \mathrm{ppbv} / \mathrm{month}$ (Table 3), consistent with the previous study ( $6.3 \mathrm{ppbv} / \mathrm{month})$. The largest contributor to the $\mathrm{O}_{3}$ seasonal trend is the $\mathrm{NO}_{\mathrm{y}} / \mathrm{PAN}$ factor $(3.55 \mathrm{ppbv} / \mathrm{month}$, Table 3 ) followed by the ${ }^{7} \mathrm{Be}$ factor (2.66 ppbv/month). That is also consistent with the previous study ( $3.5 \mathrm{ppbv} / \mathrm{month}$, and $2.5 \mathrm{ppbv} /$ month, respectively). In contrast, the simulated overall seasonal increase is only $3.01 \mathrm{ppbv} / \mathrm{month}$, indicating a large underestimation. The increase from the $\mathrm{NO}_{\mathrm{y}} / \mathrm{PAN}$ factor is underestimated (1.32 ppbv/month in the model), and the ${ }^{7} \mathrm{Be}$ factor increase is also much smaller than that of observation (1.29 ppbv/month in the model).

At high latitudes, the overall springtime increase from the measurements is $4.29 \mathrm{ppbv} / \mathrm{month}$ (Table 3 ), comparable with the previous study ( $4.6 \mathrm{ppbv} / \mathrm{month})$. In comparison, the simulated increase is only $1.3 \mathrm{ppbv} / \mathrm{month}$, indicating a significant underestimation. The most contributions to the seasonal increases at high latitudes are from ${ }^{7} \mathrm{Be}, \theta$, and $\mathrm{NO}_{\mathrm{y}} / \mathrm{PAN}$ factors $(1.78,1.16$, and $1.10 \mathrm{ppbv} / \mathrm{month}$, respectively) in the measurement dataset. In comparison, the corresponding trends in the model are much lower $(0.76,0.77$, and $0.11 \mathrm{ppbv} / \mathrm{month})$. The underestimation is particularly large for the $\mathrm{NO}_{\mathrm{y}} / \mathrm{PAN}$ factor, implying that simulated $\mathrm{O}_{3}$ production in reactive-nitrogen rich air masses does not increase as 


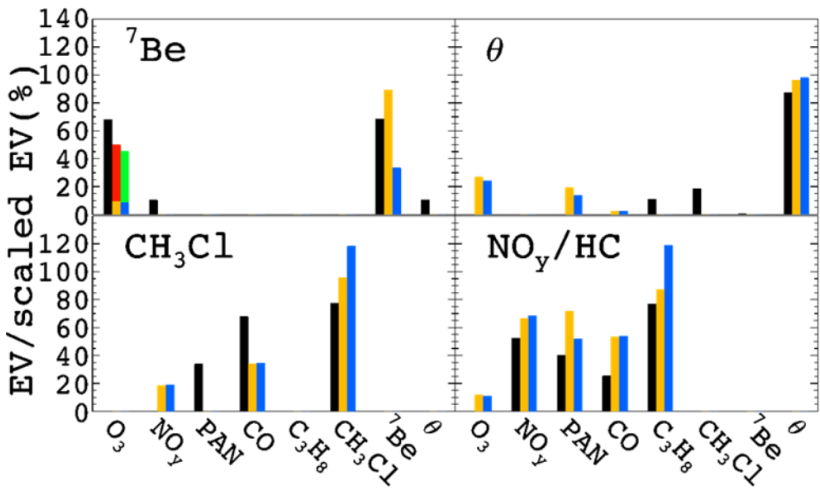

Fig. 4. Same as Fig. 2, but for TRACE-P mid latitudes $\left(30-45^{\circ} \mathrm{N}\right)$.

much as in the observations. The negative $\mathrm{O}_{3}$ trend in the hydrocarbon factor in the simulation but not in the measurements is a likely reflection of the problematic simulations of its major components $\left(\mathrm{C}_{2} \mathrm{H}_{6}\right.$ and $\left.\mathrm{C}_{3} \mathrm{H}_{8}\right)$ in May by GEOSChem (Wang and Zeng, 2004).

The $\mathrm{NO}_{\mathrm{y}} / \mathrm{PAN}$ factor trend is consistent with the previous study. However, the contributions of ${ }^{7} \mathrm{Be}$ and $\theta$ factors are different from those of the previous study $(0.8 \mathrm{ppbv} / \mathrm{month}$ and $0.6 \mathrm{ppbv} / \mathrm{month}$, respectively). The previous study had additional tracers resulting in the $\mathrm{CH}_{4}$-halocarbon factor. It accounts for transport from lower latitudes, which contributes to the largest increase of $\mathrm{O}_{3}$ at $1.7 \mathrm{ppbv} / \mathrm{month}$ at high latitudes. In this study, that large increase trend is apportioned into the ${ }^{7} \mathrm{Be}$ and $\theta$ factors since we do not have $\mathrm{CH}_{4}$ and halocarbon (other than $\mathrm{CH}_{3} \mathrm{Cl}$ ) simulations in GEOSChem. Because the PMF factor projections are for the same number of tracers, model results can still be evaluated in this analysis. The $\mathrm{CH}_{4}$-halocarbon factor contribution to $\mathrm{O}_{3}$ variability is, however, $<10 \%$ ( $3 \mathrm{ppbv}$ ) at high latitudes in the previous study; thus the effect of the missing factor on factor apportioned $\mathrm{O}_{3}$ variability is fairly insignificant in this study.

During TOPSE, the major contributions to the seasonal $\mathrm{O}_{3}$ increase in springtime is from intercontinental transport of polluted air masses, while the major contributions to $\mathrm{O}_{3}$ variability is from the stratospheric influences and long-range transport of $\mathrm{O}_{3}$ from lower latitudes. While the model generally captures the factor contributions to $\mathrm{O}_{3}$, factor contributions to the springtime increasing trend of $\mathrm{O}_{3}$ in the measurements are severely underestimated. These model underestimations are also consistent with the results by Wang et al. (2006). Improvements in the seasonal transitions of crosstropopause and intercontinental transport are needed in the model.

\subsection{TRACE-P}

The TRACE-P experiment was conducted to investigate the effects of Asian outflow to the Pacific during spring (Jacob et al., 2003). As mentioned in Sect. 2.1, the TRACE-P re-
Table 4. Same as Table 1, but for TRACE-P mid latitudes.

\begin{tabular}{lrrrrrr}
\hline & \multicolumn{2}{c}{ Latitude } & \multicolumn{2}{c}{ Altitude } & \multicolumn{2}{c}{$\mathrm{C}_{2} \mathrm{H}_{6} / \mathrm{C}_{3} \mathrm{H}_{8}$} \\
\hline Factors & Obs & Mod & Obs & Mod & Obs & Mod \\
\hline${ }^{7} \mathrm{Be}$ & -0.37 & 0.05 & 0.12 & 0.63 & 0.32 & 0.28 \\
$\theta$ & -0.33 & -0.67 & 0.79 & 0.67 & 0.86 & 0.82 \\
$\mathrm{CH}_{3} \mathrm{Cl}$ & -0.02 & 0.11 & -0.25 & -0.77 & -0.33 & -0.6 \\
$\mathrm{NO}_{\mathrm{y}} / \mathrm{HC}$ & 0.18 & -0.42 & -0.77 & -0.31 & -0.64 & -0.16 \\
\hline
\end{tabular}

sults are biased toward the middle and upper troposphere (more than $40 \%$ of the data is above $7 \mathrm{~km}$ ). Compared to TOPSE analysis, there are fewer coincident measurements limited mostly by the availability of ${ }^{7} \mathrm{Be}$ measurements $(65$ and 79 for mid and low latitudes, respectively). We analyze the datasets for low $\left(15-30^{\circ}\right)$ and $\operatorname{mid}\left(30-45^{\circ}\right)$ latitudes separately.

\subsubsection{TRACE-P at mid latitudes}

Four factors are identified for mid latitudes $\left({ }^{7} \mathrm{Be}, \theta, \mathrm{CH}_{3} \mathrm{Cl}\right.$, and $\mathrm{NO}_{\mathrm{y}}$ /hydrocarbons, Fig. 4). The ${ }^{7} \mathrm{Be}$ factor shows larger $\mathrm{O}_{3}$ variability in the observations than model results $(68 \%$ and $20.8 \mathrm{ppbv}$ for the observations, $48.5 \%$ and $13.8 \mathrm{ppbv}$ for the model). There is also a large underestimation in simulated ${ }^{7} \mathrm{Be}$ variability (428 fCi/SCM and $211 \mathrm{fCi} / \mathrm{SCM}$, respectively) for the reason discussed in Sect. 3.1.2. The tagged $\mathrm{O}_{3}$ simulation shows that $\sim 80 \%$ of $\mathrm{O}_{3}$ variability in this factor is of the stratospheric origin (Fig. 4). While this factor in the simulated dataset showed a positive correlation with altitude $(r=0.63)$, it has a much weaker correlation $(r=0.12)$ in the measurements (Table 4). One possible reason for the large difference is that transport from the stratosphere occurs too close to TRACE-P regions in the model, resulting in stronger correlations. If the stratosphere-troposphere exchange occurs in regions farther away, further downward transport or mixing with low-altitude polluted air would reduce the gradients in altitude.

The potential temperature $(\theta)$ factor shows large signals of $\theta$ (Fig. 4). Positive correlations with altitudes and $\mathrm{C}_{2} \mathrm{H}_{6} / \mathrm{C}_{3} \mathrm{H}_{8}$ ratio in Table 4 characterize this factor as longrange transport of air masses from the tropics. While this factor accounts for $25.6 \%$ of $\mathrm{O}_{3}$ variability in the simulated datasets, it has no contribution in the measurement dataset.

The $\mathrm{CH}_{3} \mathrm{Cl}$ factor is characterized by the large signals of $\mathrm{CH}_{3} \mathrm{Cl}$ and the contributions of this factor to $\mathrm{O}_{3}$ variability are small in measured and simulated datasets (Fig. 4). The significant contributions to $\mathrm{CO}$ (Fig. 4) as well as negative correlations with altitude and $\mathrm{C}_{2} \mathrm{H}_{6} / \mathrm{C}_{3} \mathrm{H}_{8}$ ratio (Table 4), and the reactive nitrogen signals suggest a strong influence from biomass burning. This factor contributes to $\mathrm{NO}_{\mathrm{y}}$ vaiability (168 pptv) only in the simulated dataset, and PAN variability (164 pptv) only in the observed dataset. Since PAN is an 


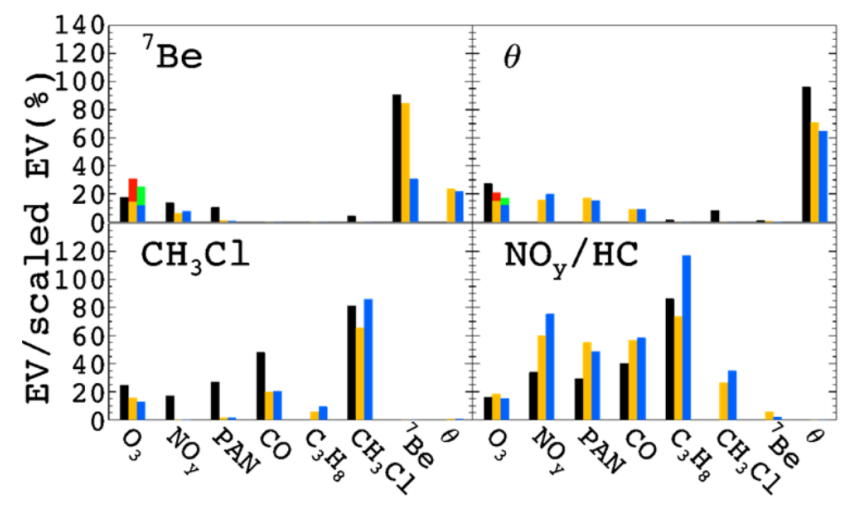

Fig. 5. Same as Fig. 2, but for TRACE-P low latitudes $\left(15-30^{\circ} \mathrm{N}\right)$.

important component of $\mathrm{NO}_{\mathrm{y}}$, the signal in PAN will propagate to become a signal of $\mathrm{NO}_{\mathrm{y}}$. However, another large component of $\mathrm{NO}_{\mathrm{y}}$ is $\mathrm{HNO}_{3}$, which can be removed rapidly by wet deposition in the atmosphere. It appears to suggest that the scavenging of $\mathrm{HNO}_{3}$ (a major component of $\mathrm{NO}_{\mathrm{y}}$ ) during transport and the production of PAN from biomass burning $\mathrm{NO}_{\mathrm{x}}$ are underestimated by the model. The stronger negative correlation of the factor with altitude (Table 4) suggests that the altitude of biomass burning transport is lower in the model. This model bias also leads to a higher negative correlation with $\mathrm{C}_{2} \mathrm{H}_{6} / \mathrm{C}_{3} \mathrm{H}_{8}$ as is found here because mixing with locally emitted $\mathrm{C}_{2} \mathrm{H}_{6}$ and $\mathrm{C}_{3} \mathrm{H}_{8}$ tends to destroy the negative correlation (Table 4).

In TRACE-P analysis, the $\mathrm{NO}_{\mathrm{y}} / \mathrm{PAN}$ and hydrocarbon factors in TOPSE are combined (now $\mathrm{NO}_{\mathrm{y}}$ /hydrocarbon factor) because the separation of those factors leads to incomparable factor profiles between the measurements and model results. The $\mathrm{NO}_{\mathrm{y}} /$ hydrocarbon factor is characterized by a large variability of $\mathrm{NO}_{\mathrm{y}}$, PAN, $\mathrm{CO}$, and $\mathrm{C}_{3} \mathrm{H}_{8}$ (Fig. 4). This factor shows a contribution to tropospheric $\mathrm{O}_{3}$ variability only in the simulation $(14.5 \%)$. This factor has negative correlations with altitudes and $\mathrm{C}_{2} \mathrm{H}_{6} / \mathrm{C}_{3} \mathrm{H}_{8}$ ratio, likely reflecting relatively the influence of fresh industrial/fossil fuel emissions over Asia (Table 4). The stronger negative correlations with $\mathrm{C}_{2} \mathrm{H}_{6} / \mathrm{C}_{3} \mathrm{H}_{8}$ ratio and altitude in the measurements than the simulations imply that mixing is too fast at low altitudes in the model.

\subsubsection{TRACE-P at low latitudes}

Four factors also are identified for low latitudes $\left({ }^{7} \mathrm{Be}, \theta\right.$, $\mathrm{CH}_{3} \mathrm{Cl}$, and NOy/hydrocarbons, Fig. 5). The ${ }^{7} \mathrm{Be}$ factor shows smaller $\mathrm{O}_{3}$ variability in the measurements than the model simulation (17.4\% and $7.1 \mathrm{ppbv}$ for the observations, and $30.8 \%$ and $9.9 \mathrm{ppbv}$ for the model). Large underestimation by a factor of 3 is found in simulated ${ }^{7} \mathrm{Be}$ variability (Fig. 5). There are no data with $\mathrm{O}_{3}$ above $100 \mathrm{ppbv}$ in both observations and simulation results at low latitudes. The stratospheric $\mathrm{O}_{3}$ fraction from the tagged $\mathrm{O}_{3}$ simulation
Table 5. Same as Table 1, but for TRACE-P low latitudes.

\begin{tabular}{lrrrrrr}
\hline & \multicolumn{2}{c}{ Latitude } & \multicolumn{2}{c}{ Altitude } & \multicolumn{2}{c}{$\mathrm{C}_{2} \mathrm{H}_{6} / \mathrm{C}_{3} \mathrm{H}_{8}$} \\
\hline Factors & Obs & Mod & Obs & Mod & Obs & Mod \\
\hline${ }^{7} \mathrm{Be}$ & 0.33 & -0.06 & 0.39 & 0.67 & 0.06 & 0.41 \\
$\theta$ & -0.05 & 0 & 0.98 & 0.93 & 0.61 & 0.52 \\
$\mathrm{CH}_{3} \mathrm{Cl}$ & 0.22 & 0.4 & 0.03 & 0.13 & -0.33 & -0.4 \\
$\mathrm{NO}_{\mathrm{y}} / \mathrm{HC}$ & 0.25 & 0.35 & -0.65 & -0.53 & -0.68 & -0.75 \\
\hline
\end{tabular}

shows that $\sim 50 \%$ is due to transport from the stratosphere (Fig. 5), which is the smallest stratospheric influence among the datasets. The positive factor correlations with altitude reflect in part the contribution from the stratosphere (Table 5). The weaker correlations with altitude and $\mathrm{C}_{2} \mathrm{H}_{6} / \mathrm{C}_{3} \mathrm{H}_{8}$ ratio in the observed than simulated datasets likely reflect either a problem in the transport locations from the stratosphere or the mixing between stratospheric and tropospheric air masses in the model (Table 5).

The potential temperature $(\theta)$ factor shows large signals of $\theta$ (Fig. 5). While the ${ }^{7} \mathrm{Be}$ factor is the largest contributor to simulated $\mathrm{O}_{3}$ variability at low latitudes, the $\theta$ factor is the largest contributor to observed $\mathrm{O}_{3}$ variability $(27.4 \%$ and $11.1 \mathrm{ppbv}$ for the observations, and $21 \%$ and $6.7 \mathrm{ppbv}$ for the model). The model estimates a small stratospheric fraction of $15 \%$ in this factor. This factor contains small signals of simulated $\mathrm{NO}_{\mathrm{y}}, \mathrm{PAN}$, and $\mathrm{CO}$, which are absent in the observed dataset, indicating again that mixing of different air masses in the model is overestimated. The correlation coefficients are more consistent between observed and simulated datasets for this factor. The positive correlations with altitude and $\mathrm{C}_{2} \mathrm{H}_{6} / \mathrm{C}_{3} \mathrm{H}_{8}$ ratio (Table 5) and negative correlations with $\mathrm{CO}(r=-0.66$ and -0.49 , not shown in the table) suggest the dominance of photochemically aged upper tropospheric air in this factor.

The $\mathrm{CH}_{3} \mathrm{Cl}$ factor is characterized by large signals of $\mathrm{CH}_{3} \mathrm{Cl}$ and a significant contribution to $\mathrm{O}_{3}$ variability is found in this factor $(24.6 \%$ and $9.9 \mathrm{ppbv}$ for the observations, $15.7 \%$ and $5 \mathrm{ppbv}$ for the model, Fig. 5). This factor contributes more to $\mathrm{O}_{3}$ in the observations than the model. The larger contribution in the observations is associated with $\mathrm{CO}, \mathrm{NO}_{\mathrm{y}}$, and PAN. In comparison, this factor in the simulated dataset has a smaller contribution from $\mathrm{CO}(22 \%$ and $17.4 \mathrm{ppbv}$ ) and negligible contributions from $\mathrm{NO}_{\mathrm{y}}$ and PAN. The observed profile is consistent with the characteristics of biomass burning.

It appears that the contributions to $\mathrm{PAN}, \mathrm{NO}_{\mathrm{y}}$, and $\mathrm{CO}$ from biomass burning are attributed to the $\mathrm{NO}_{\mathrm{y}} /$ hydrocarbon factor in the model. Comparing the profiles between $\mathrm{CH}_{3} \mathrm{Cl}$ and $\mathrm{NO}_{\mathrm{y}}$ /hydrocarbon factors, a major separation factor between these factors is the correlation between $\mathrm{C}_{3} \mathrm{H}_{8}$ and $\mathrm{CH}_{3} \mathrm{Cl}$. In both datasets, almost all the $\mathrm{C}_{3} \mathrm{H}_{8}$ signals are in the $\mathrm{NO}_{\mathrm{y}} /$ hydrocarbon factor. There is no correlation between 


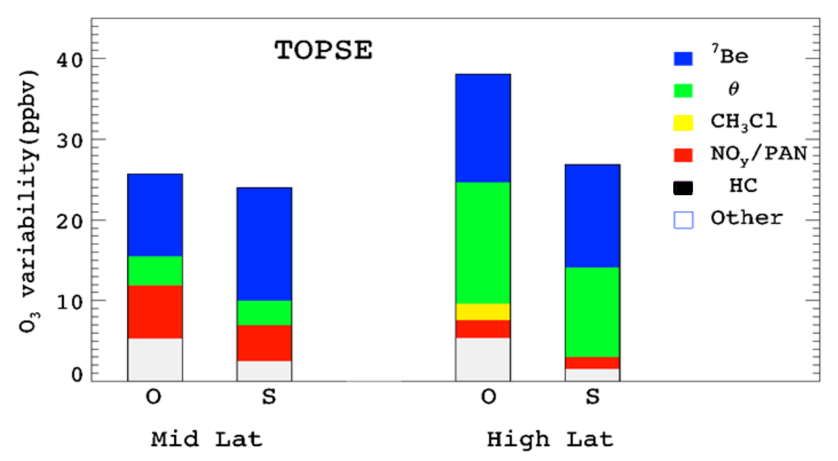

Fig. 6. $\mathrm{O}_{3}$ variability $\left(\left[\mathrm{O}_{3}\right]_{\text {average }}-\left[\mathrm{O}_{3}\right]_{\min }\right)$ by factors for TOPSE. The two bars on the left are for mid latitudes and the two bars on the right are for high latitudes. "O" and "S" denote "observations" and "simulation", respectively. "Other" denotes the unexplained fractions by PMF. "HC" denotes hydrocarbon.

$\mathrm{C}_{3} \mathrm{H}_{8}$ and $\mathrm{CH}_{3} \mathrm{Cl}$ in the observed dataset. Consequently there is no $\mathrm{CH}_{3} \mathrm{Cl}$ signal in the observed $\mathrm{NO}_{\mathrm{y}}$ /hydrocarbon factor. The opposite is true in the simulated dataset, leading to a significant contribution to the $\mathrm{CH}_{3} \mathrm{Cl}$ variability (29\% and $17 \mathrm{pptv}$ ). The inadequate separation of $\mathrm{C}_{3} \mathrm{H}_{8}$ and $\mathrm{CH}_{3} \mathrm{Cl}$ in the model may result from two sources. The first is that mixing is overestimated in the model, which results in excessive mixing of biomass burning and industrial/urban air masses. The second is that the locations of biomass burning or industrial/urban sources are misplaced in the model, which also leads to unrealistic mixing.

The $\mathrm{NO}_{\mathrm{y}}$ /hydrocarbon factor is characterized by large variabilities of $\mathrm{NO}_{y}, \mathrm{PAN}, \mathrm{CO}$, and $\mathrm{C}_{3} \mathrm{H}_{8}$ (Fig. 5). The factor contributions to these trace gases are lower in the observations than the model results because some of the enhancements in the model are due in part to biomass burning emissions. Interestingly, the factor contributions to tropospheric $\mathrm{O}_{3}$ variability are comparable in the observations (16\% and $6.5 \mathrm{ppbv})$ and model results (18.5\% and $6 \mathrm{ppbv}$ ) even though the enhancements in $\mathrm{NO}_{\mathrm{y}}, \mathrm{PAN}$, and $\mathrm{CO}$ are higher in the model results. The two datasets have comparable positive factor correlations with latitude, and large negative correlations with altitude and $\mathrm{C}_{2} \mathrm{H}_{6} / \mathrm{C}_{3} \mathrm{H}_{8}$ ratio indicating fresh pollution plumes from East Asia (Table 5).

\section{Discussion and conclusions}

Trace gas measurements of TOPSE and TRACE-P experiments and corresponding GEOS-Chem simulations are analyzed with the PMF method. The factor attributions based on the projections in the factor space allow a direct evaluation of model performance in simulating source contributions to tropospheric $\mathrm{O}_{3}$ variability and its springtime increase (during TOPSE). We select a suite of relatively long-lived variables, which are available both in observations and GEOS-

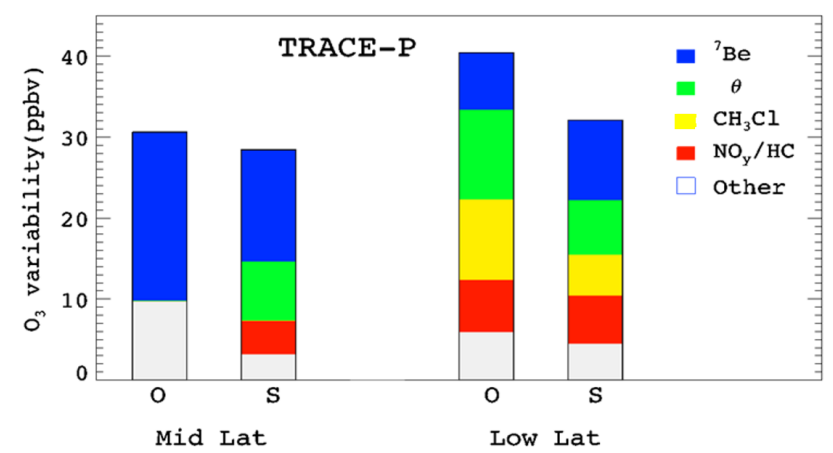

Fig. 7. Same as Fig. 6, but for TRACE-P. Two bars on the left are for mid latitudes and the two bars on the right for low latitudes.

Chem model: seven chemicals $\left(\mathrm{O}_{3}, \mathrm{NO}_{\mathrm{y}}, \mathrm{PAN}, \mathrm{CO}, \mathrm{C}_{3} \mathrm{H}_{8}\right.$, $\mathrm{CH}_{3} \mathrm{Cl}$, and ${ }^{7} \mathrm{Be}$ ) and one dynamic tracer (potential temperature). The evaluation has a bias towards a high altitude of $5-8 \mathrm{~km}(\sim 70 \%$ of the data) for TOPSE and $7-12 \mathrm{~km}(\sim 50 \%$ of the data) for TRACE-P, due to the availability of ${ }^{7} \mathrm{Be}$ measurements.

In general, the factor loadings between the observations and simulations are in better agreement during the TOPSE experiment than TRACE-P. The former experiment took place in remote regions. Therefore, the model results are not as sensitive to source locations as for the latter experiment. There are also slightly more data points (determined largely by the availability of ${ }^{7} \mathrm{Be}$ measurements) in the former experiment. We summarize the factor contributions to $\mathrm{O}_{3}$ variability in Figs. 6 and 7.

The ${ }^{7} \mathrm{Be}$ factor is found in all regions. Among all the factors, the largest discrepancy is found in the variability of ${ }^{7} \mathrm{Be}$, which is controlled largely by its source in the stratosphere. The simulated results are a factor of 2-3 lower than those observed. The large underestimation is due to the default reduction of the stratospheric ${ }^{7} \mathrm{Be}$ source by a factor of $\sim 3$. Inadvertently, the default reduction provides a test for the PMF analysis.

Tagged $\mathrm{O}_{3}$ simulations in the model indicate that the $\mathrm{O}_{3}$ signal in the ${ }^{7} \mathrm{Be}$ factor is controlled largely $(70-80 \%)$ by transport from the stratosphere at mid and high latitudes. Only over the lower latitude does the stratospheric contribution drop to $\sim 50 \%$. The ${ }^{7} \mathrm{Be}$ factor explains $34-40 \%$ of $\mathrm{O}_{3}$ variability in the measurement dataset during TOPSE, in agreement with the simulated dataset. During TRACE-P, this factor contributes $68 \%$ and $17 \%$ at mid and low latitudes, respectively in the measurement dataset. In comparison, the contributions in the simulated datasets are also higher at mid latitudes (49\%) and lower at low latitudes (31\%). In general, we find that the decrease of stratospheric $\mathrm{O}_{3}$ contributions (and the increase of tropospheric $\mathrm{O}_{3}$ contributions) from mid to low latitudes during TRACE-P are much larger in the measured than simulated datasets. One potential reason is that 
mixing is overestimated between mid and low latitudes in the model, reducing the gradients between the two latitude bands.

Another common factor is the $\theta$ factor. There are consistent positive correlations of this factor with altitude and $\mathrm{C}_{2} \mathrm{H}_{6} / \mathrm{C}_{3} \mathrm{H}_{8}$ ratio, indicating long-range transport in the upper troposphere. The contribution of this factor to reactive nitrogen is small, reflecting likely chemical processing during transport. The large contribution to $\mathrm{O}_{3}$ variability at high latitudes during TOPSE ( $\sim 40 \%)$ in the measurement dataset is in agreement with the simulated dataset. In comparison, its contributions to mid latitudes during TOPSE are much lower in both datasets. During TRACE-P, there is no contribution from this factor to $\mathrm{O}_{3}$ variability in the measurement dataset at mid latitudes. However, $26 \%$ contribution is found in the simulated dataset. A similar situation is found for the $\mathrm{NO}_{\mathrm{y}} /$ hydrocarbon factor. Excessive mixing between mid and low latitudes could explain some of the discrepancy. Further, the unresolved portion of $\mathrm{O}_{3}$ variability is $\sim 30 \%$ in this case, much higher than the range of $11-19 \%$ in the other cases. Some of the unresolved portion is due to $\mathrm{O}_{3}$ production in the troposphere.

A third common factor found is the $\mathrm{CH}_{3} \mathrm{Cl}$ factor. The contributions of this factor to $\mathrm{O}_{3}$ are usually small. The exception is at low latitudes during TRACE-P, when biomass burning contributes to both $\mathrm{CH}_{3} \mathrm{Cl}$ and $\mathrm{O}_{3}$. Some of the biomass burning contribution in the simulated datasets is attributed to the $\mathrm{NO}_{\mathrm{y}}$ /hydrocarbon factor since simulated $\mathrm{C}_{3} \mathrm{H}_{8}$ is correlated with $\mathrm{CH}_{3} \mathrm{Cl}$. The latter correlation was not found in the measurement dataset. Thus, we combine the $\mathrm{CH}_{3} \mathrm{Cl}$ and $\mathrm{NO}_{\mathrm{y}} /$ hydrocarbon factor contributions to $\mathrm{O}_{3}$ variability; it is somewhat higher in the measurement dataset (41\%) than the simulated dataset (34\%). As discussed previously, the difference can be reduced if mixing is reduced between mid and low latitudes in the model.

During TOPSE, the $\mathrm{NO}_{\mathrm{y}} / \mathrm{PAN}$ factor is resolved separately from the hydrocarbon factor. The latter made no contribution to $\mathrm{O}_{3}$ variability. The $\mathrm{NO}_{\mathrm{y}} / \mathrm{PAN}$ factor contributions are much higher at mid latitudes (18-26\%) than high laitutdes $(<5 \%)$ in measured and simulated datasets, reflecting more active photochemistry at mid latitudes in spring.

Since the TOPSE experiment lasted longer than TRACE$\mathrm{P}$, we compared the factor contributions to the seasonal trend of $\mathrm{O}_{3}$ in the observed and simulated datasets. Despite reasonably good agreements in the averaged contributions, the trends of factor contributions are quite different. The observed springtime $\mathrm{O}_{3}$ increase is higher than simulated by a factor 2 at mid latitudes ( $6.5 \mathrm{vs} .3 \mathrm{ppbv} / \mathrm{month}$ ) and a factor of 3 at high latitudes ( 4.3 vs. $1.3 \mathrm{ppbv} / \mathrm{month}$ ). The increasing trend from the stratospheric contribution (the ${ }^{7} \mathrm{Be}$ factor) is underestimated by a factor of 2 . The increasing trend from the tropospheric contribution is simulated well for the $\theta$ factor. However, the increasing trend from $\mathrm{O}_{3}$ production by reactive nitrogen (the $\mathrm{NO}_{\mathrm{y}} / \mathrm{PAN}$ factor) is underestimated by a factor of $>3(3.5 \mathrm{ppbv} / \mathrm{month}$ vs. $1.3 \mathrm{ppbv} / \mathrm{month}$ at $\mathrm{mid}$ latitudes and $1 \mathrm{ppbv} / \mathrm{month}$ vs. $0.1 \mathrm{ppbv} / \mathrm{month}$ at high latitudes). These results suggest that more attention needs to be placed on improving the simulations of the temporal trends of trace gases in chemical transport models.

Acknowledgement. This work was supported by the National Science Foundation Atmospheric Chemistry Program. The GEOSCHEM model is managed at Harvard University with support from the NASA Atmospheric Chemistry Modeling and Analysis Program.

Edited by: R. von Glasow

\section{References}

Atlas, E. L., Ridley, B. A., and Cantrell, C.: Tropospheric Ozone Production about the Spring Equinox (TOPSE) Experiment: Introduction, J. Geophys. Res. 108(D4), 8353, doi:10.1029/2002JD003172, 2003.

Benkovitz, C. M., Schwartz C. E., Jensen, M. P., et al.: Global gridded inventories of anthropogenic emissions for sulfur and nitrogen, J. Geophys. Res., 101(D22), 29 239-29 253, 1996.

Berntsen, T. K., Karlsdottir S., and Jaffe D. A.: Influence of Asian emissions on the composition of air reaching the northwestern United States, Geophys. Res. Lett., 26, 2171-2174, 1999.

Bey, I., Jacob, D. J., Yantosca, R. M., et al.: Global modeling of troposheric chemistry with assimilated meteorology: Model description and evaluation, J. Geophys. Res, 106, 23 073-23 096, 2001.

Chameides, W. L., Davis, D. D., Rodgers, M. O., et al.: Net ozone photochemical production over the eastern and central north $\mathrm{Pa}$ cific as inferred from CTE/CITE 1 observations during fall 1983, J. Geophys. Res., 92, 2131-2152, 1987.

Chen, P.: Isentropic cross-tropopause mass exchange in the extratropics, J. Geophys. Res., 100, 16 661-16673, 1995.

Chin, M., Jacob, D. J., and Munger, J. W., et al.: Relationship of ozone and carbon monoxide over North America, J. Geophys. Res., 99, 14 565-14 573, 1994.

Dibb, J. E., Meeker, L. D., Finkel, R. C. J., et al.: Estimation of stratospheric input to the Arctic troposphere: ${ }^{7} \mathrm{Be}$ and ${ }^{10} \mathrm{Be}$ in aerosols at Alert, Canada, J. Geophys. Res, 99, 12 855-12 864, 1994.

Dibb, J. E., Talbot, R. W., Scheuer, E., et al.: Stratospheric influence on the northern North American free troposphere during TOPSE: ${ }^{7} \mathrm{Be}$ as a stratospheric tracer, J. Geophys. Res., 108(D4), 8363, doi:10.1029/2001JD001347, 2003.

Duncan, B. N., Martin, R. V., Staudt, A. C., et al.: Interannual and seasonal variability of biomass burning emissions constrained by satellite observations, J. Geophys. Res., 108(D2), 4100, doi:10.1029/2002JD002378, 2003.

Fishman, J. and Seiler, W.: Correlative nature of ozone and carbon monoxide in the troposphere: Implications for the tropospheric ozone budget, J. Geophys. Res., 88, 3662-3670, 1983.

Holton, J. R., Haynes P. H., McInyre, E. M., et al.: Stratospheretroposphere exchange, Rev. Geophys, 33, 403-439, 1995.

Jacob, D. J., Logan J. A., and Murti P. P.: Effect of rising Asian emissions on surface ozone in the United States, Geophys. Res. Lett., 26, 2175-2178, 1999. 
Jacob, D. J., Crawford, J. H., Kleb, M. M., et al.: Transport and Chemical Evolution over the Pacific (TRACE-P) aircraft mission: Design, execution, and first results, J. Geophys. Res., 108(D20), 1-19, 2003.

Jaffe, D., Anderson, T., Covert, D., et al.: Transport of Asian air pollution to North America, Geophys. Res. Lett., 26, 711-714, 1999.

Lee, E., Chan, C. K., and Paatero, P.: Application of positive matrix factorization in source apportionment of particulate pollutants in Hong Kong, Atmos. Envron., 33, 3201-3212, 1999.

Liu, H., Jacob, D. J., Bey, I., and Yantosca, R. M.: Constraints from ${ }^{210} \mathrm{~Pb}$ and ${ }^{7} \mathrm{Be}$ on wet deposition and transport in a global threedimensional chemical tracer model driven by assimilated meteorological fields, J. Geophys. Res., 106, 12 109-12 128, 2001.

Liu, H., Jacob, D. J., Chan, L. Y., et al.: Sources of tropospheric ozone along the Asian Pacific Rim: An analysis of ozonesonde observations, J. Geophys. Res., 107(D21), 4573, doi:10.1029/2001JD002005, 2002.

Liu, H., Jacob, D. J., Dibb, J. E., Fiore, A. M., et al.: Constraints on the sources of tropospheric ozone from ${ }^{210} \mathrm{~Pb}^{7}{ }^{7} \mathrm{Be}-\mathrm{O}_{3}$ correlations, J. Geophys. Res., 109, D07306, doi:10.1029/2003JD003988, 2004.

Liu, S. C., Trainer, M., Fehsenfeld, F. C., et al.: Ozone production in the rural troposphere and the implications for regional and global ozone distributions, J. Geophys. Res., 92, 4191-4207, 1987.

Liu, W., Wang, Y., Russell, A., et al.: Atmospheric aerosols over two urban-rural pairs in southeastern United States: Chemical composition and sources, Atmos. Environ., 39, 4453-4470, 2005.

Logan, J. A.: Tropospheric ozone: Seasonal behavior, trends, and anthropogenic influence, J. Geophys. Res., 90, 10463-10 482, 1985.

Mauzerall, D. L., Narita, D., Akimoto, H., et al.: Seasonal characteristics of tropospheric ozone production and mixing ratios over East Asia: A global three dimensional chemical transport model analysis, J. Geophys. Res., 105, 17 895-17 910, 2000.

McLinden, C. A., Olsen, S. C., and Hannegan, B., et al.: Stratospheric ozone in 3- D models: A simple chemistry and the crosstropopause flux, J. Geophys. Res., 105, 14 653-14 665, 2000.

Olivier, J. G. J. and Berdowski, J. J. M.: Global emissions sources and sinks, in: The Climate System, edited by: Berdowski, J., Guicherit, R., and Heij, B. J., A. A. Balkema Publishers/Swets \& Zeitlinger Publishers, Lisse, The Netherlands, ISBN 90-5809255-0, 33-78, 2001.

Oltmans, S. J. and Levy II, H.: Seasonal cycle of surface ozone over the western North Atlantic, Nature, 358, 392-394, 1992.

Paatero, P. and Tapper, U.: Positive Matrix Factorization: a nonnegative factor model with optimal utilization of error estimates of data values, Environmetrics, 5, 111-126, 1994.
Paatero, P.: Least squares formulation of robust non-negative factor analysis, Chemomet. Intell. Lab. Sys., 37, 23-35, 1997.

Paatero, P., Hopke, P. K., Song, X.-H., et al.: Understanding and controlling rotations in factor analytic models, Chemomet. Intell. Lab. Sys., 60, 253-264, 2002.

Parrish, D. D., Holloway, J. S., Trainer, M., et al.: Export of North American ozone pollutions to the North Atlantic Ocean, Science, 259, 1436-1439, 1993.

Penkett, S. A. and Brice K. A.: The spring maximum in photooxidants in the Northern Hemisphere troposphere, Nature, 319, 655-657, 1986.

Shim, C., Wang, Y., Singh, H. B., et al.: Source characteristics of oxygenated volatile organic compounds and hydrogen cyanide, J. Geophys. Res., 112, D10305, doi:10.1029/2006JD007543, 2007.

Tanimoto, H., Wild, O., Kato, S., et al.: Seasonal cycles of ozone and oxidized nitrogen species in northeast Asia: 2. A model analysis of the roles of chemistry and transport, J. Geophys. Res., 107(D23), 4706, doi:10.1029/2001JD001497, 2002.

Wang, Y., Jacob, D. J., and Logan, J. A.: Global simulation of tropospheric $\mathrm{O}_{3}-\mathrm{NO}_{\mathrm{X}}$-hydrocarbon chemistry, 3. origin of troposheric ozone and effects of non-methane hydrocarbons, J. Geophys. Res., 103, 10 757-10 767, 1998b.

Wang, Y., Liu, S. C., Wine, P. H., et al.: Factors Controlling Tropospheric $\mathrm{O}_{3}, \mathrm{OH}, \mathrm{NO}_{\mathrm{x}}$, and $\mathrm{SO}_{2}$ over the Tropical Pacific during PEM-Tropics B, J. Geophys. Res., 106, 32 733-32 748, 2001.

Wang, Y., Ridley, B., Fried, A., et al.: Springtime photochemistry at northern mid and high latitudes, J. Geophys. Res., 108(D4), 8358, doi:10.1029/2002JD002227, 2003a.

Wang, Y., Shim, C., Blake, N., et al.: Intercontinental transport of pollution manifested in the variability and seasonal trend of springtime $\mathrm{O}_{3}$ at northern middle and high latitudes, J. Geophys. Res., 108(D21), 4683, doi:10.1029/2003JD003592, 2003b.

Wang, Y. and T. Zeng; On tracer correlations in the troposphere: The case of ethane and propane, J. Geophys. Res., 109, D24306, doi:10.1029/2004JD005023, 2004.

Wang, Y., Choi, Y. S., Zeng, T., et al.: Late-spring increase of transPacific pollution transport in the upper troposphere, Geosphys. Res. Lett., 33, L01811, doi:10.1029/2005GL024975, 2006.

Wild, O. and Akimoto, H.: Intercontinental transport of ozone and its precursors in a three-dimensional global CTM, J. Geophys. Res., 106, 27 729-27 744, 2001.

Yoshida, Y., Wang, Y. H., Zeng, T., et al.: A threedimensional global model study of atmospheric methyl chloride budget and distributions, J. Geophys. Res., 109, D24309, doi:24310.21029/2004JD004951, 2004. 